\title{
Editorial
}

\section{Reputation management in times of crisis}

Journal of Brand Management (2009) 16, 499-503. doi:10.1057/bm.2009.7

Nokia's chairman Olli-Pekka Kallasvuo probably faced the toughest annual results press conference of his career on 24 January 2008. During the previous weeks, he had been torn apart by the German media as an unconscionable capitalist and a 'job killer' who puts the profit motives of a few before the well-being of many. Since the company's announcement that it would close its plant in Bochum, Germany, and would shift the production to other European sites with lower labor costs, anti-Nokia anger had been relentless. German politicians publicly discarded the company's mobile phones, demanded that the company repay the German government subsidies, and called for a national boycott in what is Europe's largest economy. A survey by the market research institute Psychonomics, released soon after the announcement, signaled that Nokia's image had suffered massively. Psychonomic's BrandIndex, a daily measure of public perception based on over 1000 respondents, instantly experienced a slump in the Nokia brand equity. Triggered by the massive negative media coverage, consumers suddenly gave Nokia lower quality, satisfaction and value ratings after having previously compared it favorably to competitors like Sony Ericsson and Samsung (Figure 1). The company faced a severe communication crisis fueled by savvy consumers who used forums and blogs to rally protesters. ${ }^{1}$ Nokia has not as yet fully recovered from this development.

This is just one of the numerous corporate crises of the last decades through which companies have suffered a severe loss of reputation. With Nokia, the loss of reputation was primarily a result of poor communicational efforts. In other cases, a perceived lack of corporate social responsibility, such as Nike's exploitation of cheap Asian labor, or Wal Mart's predatory pricing strategies aimed at driving traditional mom-and-pop stores out of business, may cause such a loss of reputation. ${ }^{2}$ Most of these crises involve events whose resolution managers can influence directly by anticipating and planning response scenarios and managing key stakeholders' expectations.

However, matters are more complicated in the current financial crisis. This is not because managers are uncertain of its scope or the full potential of its impact, nor is it because they are unsure of its duration or how it might ultimately be resolved. Currently, as in the aftermath of $9 / 11$, the company cannot change the course or outcome of this crisis by itself. It is a pervasive crisis of confidence characterized by mass insecurity. Nonetheless even in such a severe crisis, corporate reputation should be protected because its positive effects go well beyond the scope of a crisis situation. 


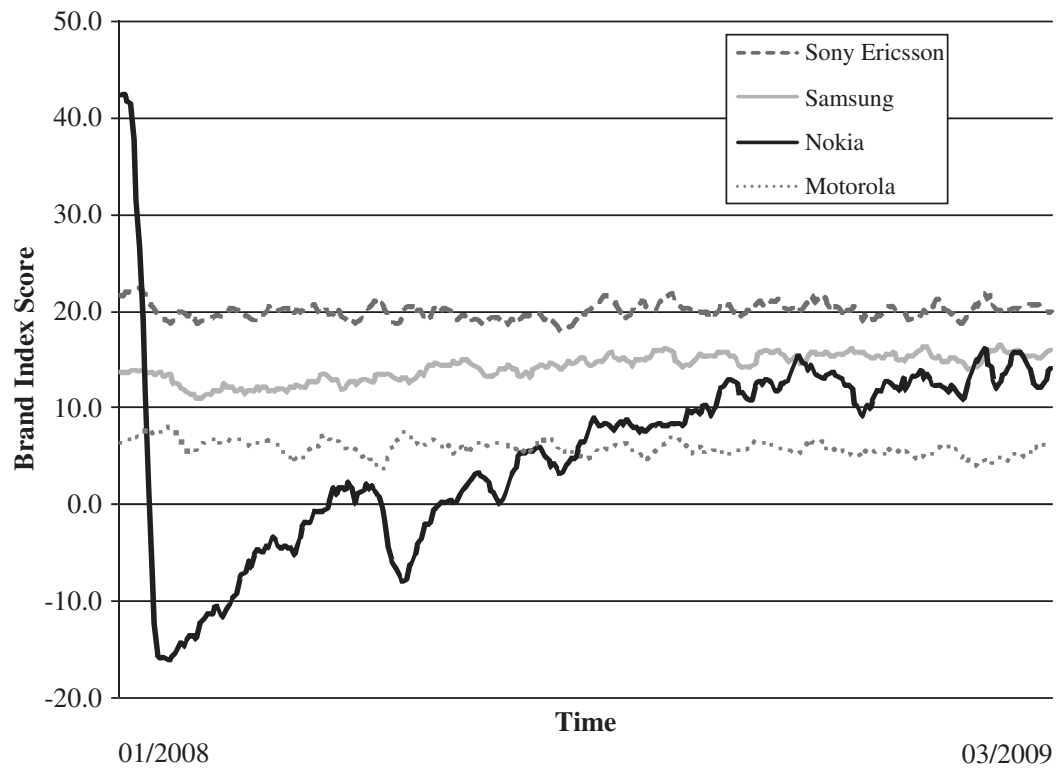

Figure I: Brandlndex measures in respect of Nokia in Germany (January 2008-March 2009).

Here are just some of many recent research findings showing how companies can benefit from a pronounced corporate reputation in the long run. Corporate reputation ...

- ... is an early indicator of capital market performance as it serves as a riskreducing signal for investors' expectations about future cash flows. ${ }^{3}$

- ... can compensate negative product attributes and increases consumers' willingness to pay. ${ }^{4}$

- ... positively influences customer satisfaction and loyalty within consumer segments. ${ }^{5,6}$

- ... positively influences the size and quality of a company's applicant pool. ${ }^{7}$

On examining these recent research findings, it becomes clear that corporate reputation is a strategic success factor that competitors cannot easily imitate. ${ }^{8}$

However, when corporate reputation management disappears from the formal management agenda, the company jeopardizes one of its most important intangible assets. This can harm companies significantly in the long run. Despite the widely acknowledged importance of intangible assets in today's business world (even in the recent stock market crash, intangibles account for more than 35 per cent of a public company's market value), many marketers are in a defensive crouch, waiting for the credit crunch tsunami to pass. There seem to be three reasons for this state of affairs.

First, despite the abundance of reputation research, many managers do not fully appreciate the value of a good corporate reputation. For example, only a minority of companies in the United States (38 per cent) and Germany (35 per cent) consider the monitoring of reputation efforts to be a board level concern. ${ }^{9}$ However, in research, corporate reputation has gained much attention because it captures the effects that brands have on stakeholders' overall evaluations of companies. Therefore, reputation can serve as a useful function to gauge the overall estimation with which its constituents regard the organization, and thus measure the effectiveness of the organization's communications 
with those stakeholders. ${ }^{10}$ Consequently, researchers need to do a better job to communicate such findings and ensure their scientific rigor and practical relevance in respect of establishing a stronger link between marketing research and practice. In this context, the Journal of Brand Management will retain its imperative role in communicating the latest corporate branding research.

Second, most managers (as well as researchers) only have a fuzzy understanding of how reputation is formed. Although managers may feel that their company does not receive the social status it deserves, it is not clear what can be done to rectify this situation.

The lack of a conceptual framework leads to a third problem - how to measure what the various stakeholder groups think about the company. ${ }^{11}$ If you cannot measure the facets or drivers of corporate reputation, this strategic asset cannot be managed. What's problematic, though, is that measuring corporate reputation has been subject to considerable research over the past years that has led to a variety of approaches. ${ }^{12}$ In his compilation of international corporate reputation ratings, Fombrun ${ }^{13}$ identifies 183 public lists that provide rankings of companies in 38 countries. Such lists are of great importance for managers, as they call attention to companies' activities and thus influence their appreciation by different stakeholder groups, such as the media, customers, politicians and the financial community. However, most lists are based on different conceptualizations and operationalizations of corporate reputation, thus leading to inconsistent company ratings. An example is the ranking of the top 10 companies in 2007 according to the following prominent reputation rankings: Fortune's America's most admired companies (AMACs), the reputation quotient (RQ) and Cision's media reputation index (Table 1).

By merely comparing the top 10 companies across the different rankings, it becomes
Table I: Top 10 companies in the AMAC, RQ and Cision's media reputation indices (2007)

\begin{tabular}{|c|c|c|c|}
\hline \multirow[t]{2}{*}{ Rank } & \multicolumn{3}{|c|}{ Reputation index } \\
\hline & $A M A C$ & $R Q$ & Cision \\
\hline I & General Electric & Google & Microsoft \\
\hline 2 & Starbucks & $\begin{array}{l}\text { Johnson \& } \\
\text { Johnson }\end{array}$ & $\begin{array}{l}\text { General } \\
\text { Motors }\end{array}$ \\
\hline 3 & Toyota Motor & Intel & AT\&T \\
\hline 4 & $\begin{array}{l}\text { Berkshire } \\
\text { Hathaway }\end{array}$ & General Mills & Intel \\
\hline 5 & $\begin{array}{l}\text { Southwest } \\
\text { Airlines }\end{array}$ & Kraft foods & Verizon \\
\hline 6 & FedEx & $\begin{array}{l}\text { Berkshire } \\
\text { Hathaway }\end{array}$ & Walt Disney \\
\hline 7 & Apple & $3 M$ & Wal-Mart \\
\hline 8 & Google & Coca-Cola & Boeing \\
\hline 9 & $\begin{array}{l}\text { Johnson \& } \\
\text { Johnson }\end{array}$ & Honda & Cisco \\
\hline 10 & $\begin{array}{c}\text { Procter \& } \\
\text { Gamble }\end{array}$ & Microsoft & $\begin{array}{l}\text { News } \\
\text { Corporation }\end{array}$ \\
\hline
\end{tabular}

hard, if not almost impossible, to tell whether or not a company has a real reputation problem. The available approaches provide valuable insights, but the lack of consensus must certainly be considered the greatest obstacle to an effective reputation management. With tight budgets and a stronger focus on return on investment (ROI), it is more important than ever to understand the levers of an effective reputation management.

Many of these inconsistencies are due to a lack of scientific standards in scale development procedures, which result from ambiguous conceptualizations or operationalizations, financial halo effects and the omitting of important stakeholder groups in the analysis. ${ }^{14}$ Reputation research offers several very promising alternatives to compensate for the deficiencies mentioned above. ${ }^{15}$ Most of these are based on rigid scale development procedures, thus ensuring the scales' reliability and validity. In this context, Schwaiger's ${ }^{14}$ two-dimensional measurement approach for reputation stands out due to its psychometric properties and advantages with regard to management applications. ${ }^{16}$ It has been frequently applied in research studies ${ }^{17}$ and successfully adapted 
by several multinational companies in the European Centre for Reputation Studies as a metric for corporate reputation management. ${ }^{18}$ However, if at all, most companies still rely on more common approaches that lack validity, and thus, do not provide a sound basis for an effective reputation management.

In the light of the discussion above, there are several issues that both marketers and researchers should consider in their future work.

In times of crisis, companies must look beyond their corporate borders to manage corporate reputation effectively. A crisis involving an individual firm may, for example, cast a bad light on an entire industry and all its affiliated companies. In most cases, the loss of reputation is the result of a company's own short-sighted business and communication tactics. For example, JP Morgan came under fire after it was revealed that the company intended to purchase two private jets and renovate a jet hangar for 138 million US\$ although it had needed 25 billion US $\$$ from the Troubled Asset Relief Program. This was grist to the mills of various critics who excoriated the entire industry. In light of this reaction, it has become clear that an industry's collective reputation has an increasingly important role to play. Consequently, industry members should jointly mobilize their resources and plan actions to counteract environmental pressures. $^{19}$

Likewise, marketers need to develop a better understanding of metrics to measure the effects of corporate branding and reputational efforts. Many marketers do have well-grounded analytical skills, but this cannot be said of them all. ${ }^{20}$ This is not only about understanding numbers and measurements, but also about interpreting these in a meaningful way. It also means realizing the measurements' strengths and weaknesses. Even though there is no silver bullet for measuring complex constructs, such as corporate reputation, it is nevertheless essential that both marketers and researchers develop a thorough understanding of the quality and performance of these different measurement concepts.

Consequently, researchers have to thoroughly investigate the available measures with regard to their psychometric properties. In this context, researchers should ensure that the procedures are flexible enough to be applied in different contexts. This requires replication studies of existing measures to evaluate whether these perform robustly across different countries and industries.

Reputation matters, especially today. The road toward accomplishing more with reputation management does not require bigger budgets, merely using existing funds more productively. This requires a better understanding of the levers of an effective reputation management across all stakeholder groups.

\section{REFERENCES}

(1) Sarstedt, M. and Schwaiger, M. (2008) Sorry, we're closed - Nokia's communication crisis in Germany. Management Case Study Journal 8(2): 147-160.

(2) Argenti, P.A. (2007) Corporate Communication, 4th edn. Boston, MA: McGraw-Hill.

(3) Raithel, S. (2009) The Value of Corporate Reputation for Shareholders: Evidence from Germany for DAX Companies. Discussion Paper of the Munich School of Management, no. 2009-05, http://epub.ub.uni-muenchen.de/10361/.

(4) Eberl, M. (2006) Unternehmensreputation als Determinante von Kaufentscheidungen: Methodische Aspekte komplexer Strukturmodelle. Wiesbaden, Germany: DUV.

(5) Helm, S. (2007) One reputation or many? Comparing stakeholders' perceptions of corporate reputation. Corporate Communications: An International Journal 12(3): 238-254.

(6) Sarstedt, M., Ringle, C.M., Schloderer, M.P. and Schwaiger, M. (2008) Accounting for Unobserved Heterogeneity in the Analysis of Antecedents and Consequences of Corporate Reputation: An Application of FIMIX-PLS. Proceedings of the 37th Annual Conference of the European Marketing Academy, Brighton, England, CDRom Proceedings, 27-30 May 2008, EMAC.

(7) Turban, D.B. and Cable, D.M. (2003) Firm reputation and applicant pool characteristics. Journal of Organizational Behavior 24(6): 733-751. 
(8) Melewar, T.C. (2008) Facets of Corporate Identity, Communication and Reputation. London and New York: Routldge.

(9) Jones, M.C. (2003) Talking about my reputation. Brand Strategy (173): 20-22.

(10) Van Riel, C.B.M. and Fombrun, C.J. (2007) Essentials of Corporate Communication. London and New York: Routledge.

(11) Dowling, G. (2002) Creating Corporate Reputations Identity Image and Performance. Oxford: Oxford University Press.

(12) Chun, R. (2005) Corporate reputation: Meaning and measurement. International Journal of Management Review 7(2): 91-109.

(13) Fombrun, C.J. (2007) List of lists: A compilation of international corporate reputation ratings. Corporate Reputation Review 10(2): 144-153.

(14) Schwaiger, M. (2004) Components and parameters of corporate reputation - An empirical study. Schmalenbach Business Review 56(1): 46-71.

(15) Berens, G. and Van Riel, C.B.M. (2004) Corporate associations in the academic literature: Three main stream of thought in the reputation measurement literature. Corporate Reputation Review 7(2): 161-178.
(16) Wilczynski, P., Sarstedt, M. and Melewar, T.C. (2009) A Comparison of Selected Reputation Measures' Convergent and Criterion Validity, Proceedings of the 2009 Annual Conference of the Academy of Marketing Science; Baltimore, MD, 20-23 May 2009, AMS.

(17) Eberl, M. and Schwaiger, M. (2005) Corporate reputation - Disentangling the effects on financial performance. European Journal of Marketing 39(7): 838-854.

(18) ECRS, European Centre for Reputation Studies, http://www.reputation-centre.org.

(19) Winn, M. I., MacDonald, P. and Zietsma, C. (2008) Managing industry reputation: The dynamic tension between collective and competitive reputation management strategies. Corporate Reputation Review 11(1): 35-55.

(20) Uncles, M. (2005) Marketing metrics: A can of worms or the path to enlightment? Journal of Brand Management 12(6): 412-418.

Marko Sarstedt Editorial Board 